\title{
Ethanol production by a Paenibacillus species isolated from an Icelandic hot spring - Production yields from complex biomass
}

\author{
Jan Eric Jessen $^{1}$, Thoroddur Sveinsson ${ }^{2}$, Sean Michael Scully ${ }^{1}$ and Johann Orlygsson ${ }^{1 *}$ \\ ${ }^{1}$ University of Akureyri, Faculty of Natural Resource Sciences, Borgir, Nordurslod 2, \\ 600 Akureyri, Iceland*E-mail: jorlygs@unak.is (corresponding author) \\ ${ }^{2}$ The Agricultural University of Iceland, Mödruvellir Experimental Station, IS-603, Akureyri, Iceland.
}

\begin{abstract}
Ethanol production using Paenibacillus strain J2 was studied on carbohydrates and lignocellulosic biomass hydrolysates including grass (Phleum pratense) and barley straw (Hordeum vulgare). The strain has a broad substrate spectrum; fermentation of glucose yielded ethanol (major product), acetate, butyrate (minor), hydrogen, and carbon dioxide. At glucose concentrations below $30 \mathrm{mM}$ fermentation was not inhibited. Higher substrate loadings resulted in decreased glucose utilization and a shift of end products towards butyrate. The maximum yields of ethanol were $1.45 \mathrm{~mol}$ ethanol mol glucose $\mathrm{m}^{-1}$. The end products from lignocellulosic $\left(4.5 \mathrm{~g} \mathrm{~L}^{-1} \mathrm{dw}\right)$ biomass hydrolysates pretreated with $0.5 \% \mathrm{HCl}$ or $\mathrm{NaOH}$ (control was unpretreated) prior to cellulase treatment were investigated. Ethanol production from cellulose hydrolysates without chemical pre-treatment yielded 5.5 $\mathrm{mM}$ ethanol g-1 with lower yields from paper and lignocellulosic biomasses $\left(1.2-1.7 \mathrm{mM} \mathrm{g}^{-1}\right)$. Ethanol production was enhanced by dilute acid or base pre-treatment combined with enzymatic treatment with the highest yields from grass $\left(3.2 \mathrm{mM}\right.$ ethanol $\left.\mathrm{g}^{-1}\right)$.
\end{abstract}

Key words: Bioethanol, Lignocellulosic biomass, Paenibacillus, Thermophiles

\section{YFIRLIT}

Etanól framleiðsla hjá Paenibacillus, stofni J2 var rannsakaður á sykrum og hýdrólýstötum úr flóknum lífmassa, m.a. vallarfoxgrasi (Phleum pratense) og hveitihálmi (Hordeum vulgare). Stofninn var með breytt hvarfefnasvið; gerjun á glúkósa leiddi til myndunar á etanóli (meginafurð), ediksýru, smjörsýru, vetnis og koltvísýrings. Of hár upphafsstyrkur (> $30 \mathrm{mM}$ ) glúkósa leiddi til hindrunar á niðurbroti hans og aukinnar framleiðslu á smjörsýru. Hámarksframleiðsla á etanóli var 1.45 mól etanól mól glúkósa-1 ${ }^{-1}$ Lokaafurðir úr hýdrólýsötum úr flóknum lífmassa (4.5 $\mathrm{g} \mathrm{L}^{-1}$ purrvigt) sem var formeðhöndlaður með annað hvort $0.5 \% \mathrm{HCl}$ eða $\mathrm{NaOH}$ auk sellulasa meðhöndlunar var rannsökuð. Etanól framleiðsla úr sellulósa án efnafræðilegrar formeðhöndlunar gaf af sér 5.5 $\mathrm{mM}$ etanól $\mathrm{g}^{-1}$ en minni nýting var á pappír og flóknum lífmassa (1.2-1.7 $\left.\mathrm{mM} \mathrm{g}^{-1}\right)$. Etanólframleiðsla á grasi jókst með sýru- og basameðhöndlun ásamt ensímformeðhöndlun, en hámarksnýting var $3.2 \mathrm{mM}$ etanól $\mathrm{g}^{-1}$. 


\section{INTRODUCTION}

Paenibacillus is a large genus currently containing 148 species and 4 subspecies according to the Euzeby List of Prokaryotes with standing in Nomenclature (LPSN); many species are notable for their potential applications in biotechnology. Species belonging to the genus are typically gram-positive, mesophilic, endospore-forming flagellated rods that are facultative anaerobes or strict aerobes (Priest, 2009). Several moderate thermophiles within the genus have been described including $P$. thermophilus, $P$. thermoaerophilus, $P$. marinum, and $P$. tezpurensis (Zhou et al. 2012, Ueda et al. 2013, Bouraoui et al. 2013, Rai et al. 2010). The genus was originally established in 1993 (Ash et al. 1993) when Bacillus was shown to consist of at least five phyletic lines and one of them was reclassified to form the separate genus of Paenibacillus; Paenibacillus polymyxa was designated as the type species. In 1996, the genus Paenibacillus was reassessed on the basis of polyphasic taxonomic results (Heyndrickx et al. 1996). Paenibacilli can be isolated from a wide range of habitats including plant materials, soil, and geothermal areas (Ash et al. 1993, Logan et al. 2004, Khianngam et al. 2009, Behrendt et al. 2010, Zhou et al. 2012).

Ethanol production from complex biomass such as lignocellulose by using thermophilic bacteria has received increased interest in the past ten years (Taylor et al. 2009, Scully \& Orlygsson 2015). The primary reasons include the ability of many thermophiles to tolerate extremes of both temperature and $\mathrm{pH}$, their increased doubling times as compared to mesophiles, simplified end product profiles, and decreased susceptibility to mesophilic contamination. Additionally, many thermophiles have broad substrate spectra making them well suited to degrading the monomers present in complex biomass. Strict anaerobes within the genera of Clostridium, Thermoanaerobacter, and Thermoanaerobacterium have been extensively studied for their ethanol production from sugars and biomass (Wiegel et al. 1983, Lacis \& Lawford, 1988, Lynd et al. 1989, Almarsdottir et al. 2012) while little attention has been paid to other Firmicutes such as members of the genus Paenibacillus. Few reports on the fermentative metabolism of members of Paenibacillus have been reported despite some strains being able to degrade cellulose and other polymeric substrates (Dasman et al. 2002, Daane et al. 2002). Paenibacillus macerans (formerly Bacillus macerans) has been reported to produce 1.3 mole of ethanol from one mole of glucose (Weimer, 1984a); this species is very versatile even degrading glycerol and deoxyhexoses to 1,2-propanediol (Weimer, 1984b, Gupta et al. 2009).

The present investigation was towards ethanol production by a Paenibacillus strain $\mathrm{J} 2$, isolated from an Icelandic hot spring, using both simple sugars and various lignocellulosic biomasses. Special attention was given to the effect of various culture variables on ethanol yields.

\section{MATERIALS AND METHODS}

Isolation of strain and medium

Strain J2 was isolated on glucose $(20 \mathrm{mM})$ in a basal medium $(\mathrm{BM})$ from a hot spring $\left(50^{\circ} \mathrm{C}, \mathrm{pH}\right.$ 7.4) in Grensdalur in SW Iceland, as described earlier (Sveinsdottir et al. 2009). The BM medium was prepared anaerobically by using the Hungate technique (Hungate, 1969); briefly the medium was boiled for 5-10 min and cooled while flushing with nitrogen. The mixture was then transferred to cultivation bottles closed with butyl rubber stoppers and aluminium caps and autoclaved for 60 minutes. All other components of the medium were added separately through filter-sterilized (Whatman, PES $0.45 \mu \mathrm{m}$ ) solutions. The gas phase in all experiments consisted of nitrogen $(99.999 \%$ purity, $<5$ ppm $\mathrm{O}_{2}$ ). All carbon sources used were from filter sterilized stock solutions except for polymeric substrates (cellulose, avicel, CMC, xylan, and starch) which were added prior to autoclaving. All experiments were performed at $50^{\circ} \mathrm{C}$ and $\mathrm{pH} 7.0$ without agitation. The inoculum volume was $2 \%(\mathrm{v} / \mathrm{v})$ taken from the exponential growth phase of a culture cultivated on $20 \mathrm{mM}$ glucose. All experiments were performed in duplicate. 


\section{Phylogenetic analysis}

Partial 16S rRNA analysis of a 692 nucleotide long sequence was done according to Vesteinsdottir et al. (2011) and the phylogenetic relationship has been described previously (Sveinsdottir et al. 2009).

\section{Determination of temperature and pH optimum}

To determine the $\mathrm{pH}$ optimum of the strain, it was cultivated at $50^{\circ} \mathrm{C}$ with the initial $\mathrm{pH}$ set between $\mathrm{pH} 4.0$ and 9.0 with increments of 1.0 $\mathrm{pH}$ unit. The $\mathrm{pH}$ values of the experimental bottles were adjusted with $\mathrm{HCl}$ or $\mathrm{NaOH}$. The temperature optimum was determined at $\mathrm{pH}$ 7.0 using seven different temperature ranges $\left(22,37,40,45,50,55,60,65^{\circ} \mathrm{C}\right)$. Experiments were done in $117.5 \mathrm{~mL}$ bottles with $50 \mathrm{~mL} \mathrm{BM}$ medium using glucose $(20 \mathrm{mM})$ as the carbon source. The maximum growth rate $\left(\mu_{\max }\right)$ was obtained from absorbance data as previously described (Orlygsson, 2012).

\section{Substrate utilization spectrum}

The ability of strain J2 to utilize different carbohydrates was tested in $24.5 \mathrm{~mL}$ serum bottles using a $10 \mathrm{~mL} \mathrm{BM}$ medium supplemented with various substrates. The substrates tested included xylose, arabinose, glucose, mannose, galactose, fructose, rhamnose, maltose, cellobiose, sucrose, lactose, trehalose, raffinose, starch, cellulose, CMC, avicel, xylan (oat spelt), glycerol, pyruvate, serine, and threonine. Final concentration of all substrates was $20 \mathrm{mM}$ or $0.2 \%(\mathrm{w} / \mathrm{v})$ for xylan, starch, CMC, cellulose, and avicel. Growth was measured after 5 days using an increase in optical density $(600 \mathrm{~nm})$ and hydrogen production as an indicator of positive growth. Samples with positive growth were then further analysed for, hydrogen, volatile fatty acids, and ethanol.

\section{Effect of initial glucose concentrations on end product formation}

The effect of initial glucose concentration on the growth behaviour of strain $\mathrm{J} 2$ was done by varying the concentration from 5 to $200 \mathrm{mM}$. Control bottles only contained yeast extract ( 2 $\left.\mathrm{g} \mathrm{L}^{-1}\right)$. Glucose, hydrogen, acetate, butyrate, and ethanol concentrations were measured at the beginning and at the end of the incubation period (5 days). Experiments were done in 117.5 $\mathrm{mL}$ serum bottles with $60 \mathrm{~mL}$ liquid medium.

\section{Effect of liquid gas phases}

The strain was cultivated in $117.5 \mathrm{~mL}$ serum bottles containing different amounts of liquid (2 $\mathrm{mL}, 5 \mathrm{~mL}, 10 \mathrm{~mL}, 30 \mathrm{~mL}, 60 \mathrm{~mL}$, and $90 \mathrm{~mL}$ ), thus yielding different liquid-to-gas $(\mathrm{L} / \mathrm{G})$ phase ratios (0.02 to 3.27$)$.

\section{Pretreatment of biomass and hydrolysate preparation}

Four different materials were used for the preparation of hydrolysates: Whatman filter paper (cellulose), newspaper, barley straw (Hordeum vulgare), and timothy grass (Phleum pratense). The biomass $\left(22.5 \mathrm{~g} \mathrm{~L}^{-1}\right)$ was either non-chemically treated or chemically $(0.5 \% \mathrm{HCl}$ or $\mathrm{NaOH}$ ) in addition to enzymatic treatment with cellulases (Celluclast and Novozyme 188) as earlier described (Sveinsdottir et al. 2009, Almarsdottir et al. 2012). After pretreatment, the hydrolysates were adjusted with $\mathrm{NaOH}$ or $\mathrm{HCl}$ to $\mathrm{pH} 7.0$ since the strain has a $\mathrm{pH}$ optimum between $\mathrm{pH} 7.0$ and 8.0 (Sveinsdottir et al. 2009). The hydrolysates were then filtered through $0.45 \mu \mathrm{m}$ syringe filters into sterile nitrogen-flushed serum bottles.

\section{Fermentation of hydrolysates}

Fermentation of carbohydrates present in hydrolysates was performed in $24.5 \mathrm{~mL}$ serum bottles with $8.0 \mathrm{~mL}$ of $\mathrm{BM}$ medium and 2.0 $\mathrm{mL}$ of hydrolysate for a final hydrolysate concentration of $4.5 \mathrm{~g} \cdot \mathrm{L}^{-1}$. Control samples did not contain hydrolysate, only yeast extract $(2 \mathrm{~g}$ $\left.\mathrm{L}^{-1}\right)$.

\section{Analytical methods}

Hydrogen, ethanol, and volatile fatty acids were measured by gas chromatography as previously described (Orlygsson \& Baldursson, 2007). Glucose was determined by slight modification of the anthrone method of Laurentin and Edwards (2003); briefly, centrifuged sample $(400 \mu \mathrm{L})$ was mixed with $2 \mathrm{~mL}$ of anthrone solution $(0.2 \%$ 
$[\mathrm{w} / \mathrm{v}]$ anthrone in $72 \%$ [v/v] sulfuric acid). The sample was boiled for 11 minutes and then cooled on ice. Absorbance was then measured at $600 \mathrm{~nm}$ by using a Perkin-Elmer Lambda-25 $\mathrm{UV}-\mathrm{Vis}$ spectrophotometer.

\section{RESULTS AND DISCUSSION}

Physiology

Strain $\mathrm{J} 2$ was isolated from a hot spring $\left(50^{\circ} \mathrm{C}, \mathrm{pH}\right.$ 7.4) in Iceland as described earlier (Sveinsdottir et al. 2009). The strain grows both aerobically (results not shown) and anaerobically; strain $\mathrm{J} 2$ is thus a facultative anaerobe as are many members within the genus (Priest, 2009). All data in the present investigation are on its fermentative metabolism. The strain grows at a relatively narrow temperature spectra, from $37^{\circ} \mathrm{C}$ to $55^{\circ} \mathrm{C}$ with $\mathrm{T}_{\text {opt }}$ between 45 and $50^{\circ} \mathrm{C}$ (generation time $1.76 \mathrm{~h}$ for both temperatures). The strain grows between $\mathrm{pH} 5.0$ and 8.0 with a $\mathrm{pH}_{\text {opt }}$ of 7.0 to 8.0 (generation time 1.99 to 2.05 h).

\section{Phylogeny}

The partial 16S rDNA (692 bases) sequence of strain J2 revealed that the strain belongs to the genus Paenibacillus. It has $97.9 \%$ similarity with $P$. phoenicis, $97.8 \%$ with $P$. barengoltzii, and $96.6 \%$ with $P$. taiwanensis. All these strains are mesophilic, either strict aerobes or facultative anaerobes, and do not originate from geothermal areas (Benardini et al. 2011, Osman et al. 2006, Lee et al. 2007). Among thermophilic species, strain J2 has the closest similarity to $P$. thermophiles (95.4\%), P. tezpurensis $(91.6 \%)$, P. marinum (91.2\%), and $P$. thermoaerophilus (90.6\%). The most closely related thermophile, $P$. thermophiles, is a strict aerobe. Despite its close relationship to several mesophilic strains, strain $\mathrm{J} 2$ may represent a new species based on temperature growth range and temperature optimum. This will be studied in the near future by fully sequencing the strain's 16S gene, more detailed investigation of phenotypic traits, and by DNA-DNA hybridization experiments performed with the closest related species.

\section{Substrate spectrum}

Figure 1 shows the fermentative substrate spectrum of strain J2. The strain showed moderately broad substrate spectrum producing a mixture of mainly ethanol and acetate from most of the sugars tested. Starch and xylan were also converted to ethanol and acetate. The ratio between ethanol and acetate was lowest during growth on xylose (1.08) but highest on trehalose (1.75). The highest ethanol concentration was observed on glucose, $25.9 \mathrm{~mm}$ (controls subtracted), thus producing $1.29 \mathrm{~mol}$ ethanol per mol glucose $(64.5 \%$ of theoretical yield). More oxidized substrates, such as pyruvate and serine, were predominantly converted to acetate. This is not surprising as the oxidation states of these substrates is greater compared to monosaccharides and thus there is less need to direct the electrons produced to $\mathrm{NAD}^{+}$via ethanol production. Ethanol generation by Paenibacillus species has received relatively

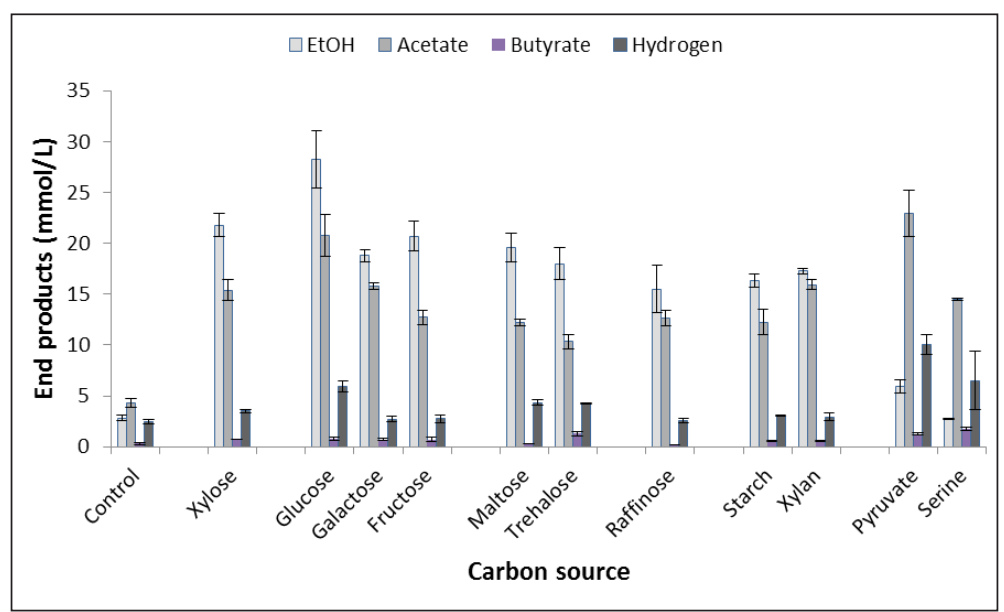

Figure 1. End product formation from various substrates by strain J2. Data represent the average of two replicate experiments. Standard deviations are shown as error bars. Hydrogen values are corrected to volume units. 
little attention although Paenibaillus macerans has been shown to produce $1.30 \mathrm{mM}$ ethanol per mol of glucose (Weimer, 1984a). Strain J2 did not utilize arabinose, mannose, rhamnose, cellobiose, sucrose, lactose, cellulose, CMC, avicel, glycerol, and threonine.

\section{Effect of different initial glucose concentrations}

One of the main obstacles of using thermophilic bacteria for ethanol production is their relatively low tolerance of high initial glucose concentrations, although this can be overcome through the use of continuous culture techniques. Low sensitivity to initial substrate concentrations has been demonstrated with thermophilic members of various genera including Clostridium (Orlygsson, 2012), Thermoanaerobacterium (Almarsdottir et al. 2012), and Thermoanaerobacter (Lacis \& Lawford 1988,

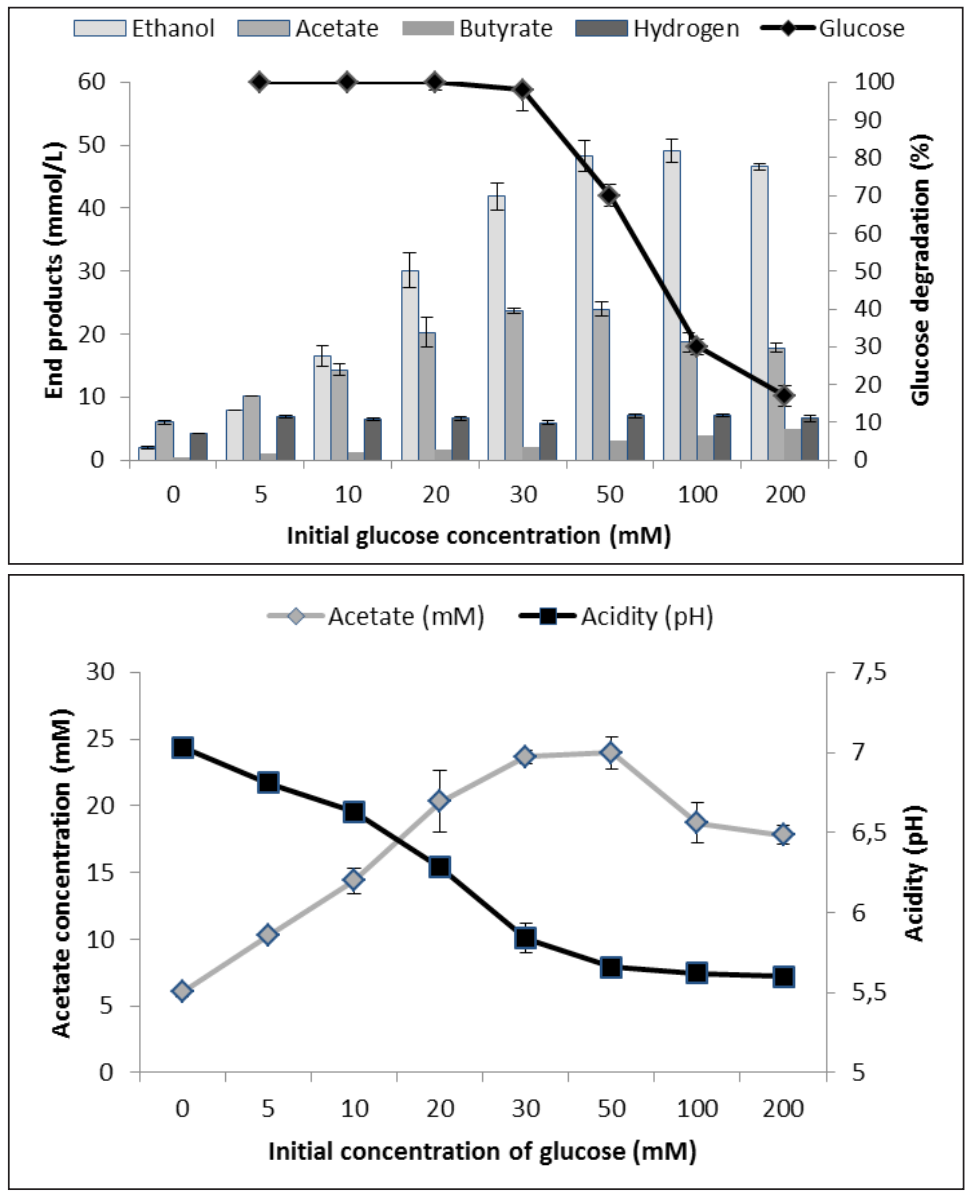

Figure 2. A) End product formation at different initial glucose concentrations. Also shown are the residual glucose concentrations (in percent) after fermentation. Data represent the average of two replicate experiments \pm standard deviations. Hydrogen values are corrected to volume units. B) Relationship between acetate and $\mathrm{pH}$ after fermentation.

Sommer et al. 2004). The main reason for this is due to the low buffer capacity of batch cultures these experiments have been performed in, end product inhibition (either acids or hydrogen), or substrate inhibition (Lacis \& Lawford, 1988). At low initial glucose concentrations $(\leq 30 \mathrm{mM})$ strain $\mathrm{J} 2$ effectively degraded most of the glucose, with ethanol as the primary end product accompanied by smaller concentrations of acetate, butyrate, and hydrogen (Figure 2A). At higher glucose concentrations, less glucose was degraded; at an initial glucose concentration of $200 \mathrm{mM}$ only $17 \%$ was degraded. The most

likely reasons for this inhibition are due to lower $\mathrm{pH}$ values observed in the experimental bottles with high glucose loadings. Paenibacillus macerans, for example, has been shown to stop carbohydrate fermentation when the $\mathrm{pH}$ drops below pH 4.9 (Weimer, 1984a). To look at the relationship between $\mathrm{pH}$ and acetate formation these data were plotted together (Figure 2B) showing that increased acetate formation leads to lower $\mathrm{pH}$ at the end of incubation. Ethanol yields per mole of glucose consumed ranged from 1.18 to 1.45 . However, there was a shift in the end product formation with increasing 
substrate loading. The strain did not produce more ethanol when the substrate concentration was increased; increased glucose loadings shifted end product formation towards butyrate rather than ethanol and acetate. The observed acetate/butyrate ratio was between 13:1 and 10:1 at concentrations of less than $30 \mathrm{mM}$ but to $3.6: 1$ at the highest glucose concentrations.

\section{Effect of different liquid-gas ratios on strain J2}

The partial pressure of hydrogen $\left(p \mathrm{H}_{2}\right)$ has been shown to be important as an inhibitor for substrate utilization in strict anaerobes (Hawkes et al. 2002, van Niel et al. 2003). To investigate the effect of $\mathrm{pH}_{2}$ on end product formation, strain J2 was cultivated with six different ratios of liquid to gas $(\mathrm{L} / \mathrm{G})$ phase on $20 \mathrm{mM}$ glucose. Figure 3 shows that the ethanol formation for strain J2 was rather stable over all the different $L / G$ ratios applied. Ethanol production was highest at the lowest $\mathrm{L} / \mathrm{G}$ ratio $(0.02)$ but acetate, butyrate, and hydrogen production decreased with higher $\mathrm{L} / \mathrm{G}$ ratios. In all the cultures the amount of ethanol observed was between 23.1 and 31.2 $\mathrm{mM}$, and the amount of acetate between 10.0 and $15.6 \mathrm{mM}$. It is a well-known phenomenon that the partial pressure of hydrogen $\left(\mathrm{pH}_{2}\right)$ strongly influences strict anaerobic bacteria that possess the pyruvate ferredoxin oxidoreductases for hydrogen production (Ben-Bassat et al. 1981, Jones, 2008, Hawkes et al. 2002). Thus, high $\mathrm{pH}_{2}$ inhibits hydrogenases and directs the electron flow to more reduced end products like ethanol, butyrate and lactate (Levin et al. 2004, Nath \& Das, 2004). Indeed, for strain J2, hydrogen together with acetate and butyrate production decreased with increasing $\mathrm{L} / \mathrm{G}$ phases but ethanol production did not increase (Figure 3). The main reason for this could be that the strain may not possess pyruvate ferredoxin oxidoreductase but pyruvate formate lyase as demonstrated in strains of $P$. macerans (Weimer, 1984a). P. macerans produces $1.3 \mathrm{~mol}$ ethanol mol glucose ${ }^{-1}$ but during kinetic study of the strain a late appearance of hydrogen and disappearance of formate suggest that formate is cleaved to hydrogen and carbon dioxide (Weimer, 1984a). Also, results indicated that the reducing equivalents for ethanol production were not only derived from the oxidation of glucose to pyruvate but also from pyruvate degradation to formate and hydrogen. Unfortunately, formate was not analysed in the present study but our results suggest a similar fermentation pattern could be present in strain $\mathrm{J} 2$. It has been shown that Paenibacillus macerans also produces more ethanol when exogenous hydrogen is added to closed batch fermentation on glucose (Weimer, 1984a) but this strain is also known to convert acetate to acetone at low $\mathrm{pH}$.

\section{Hydrolysates}

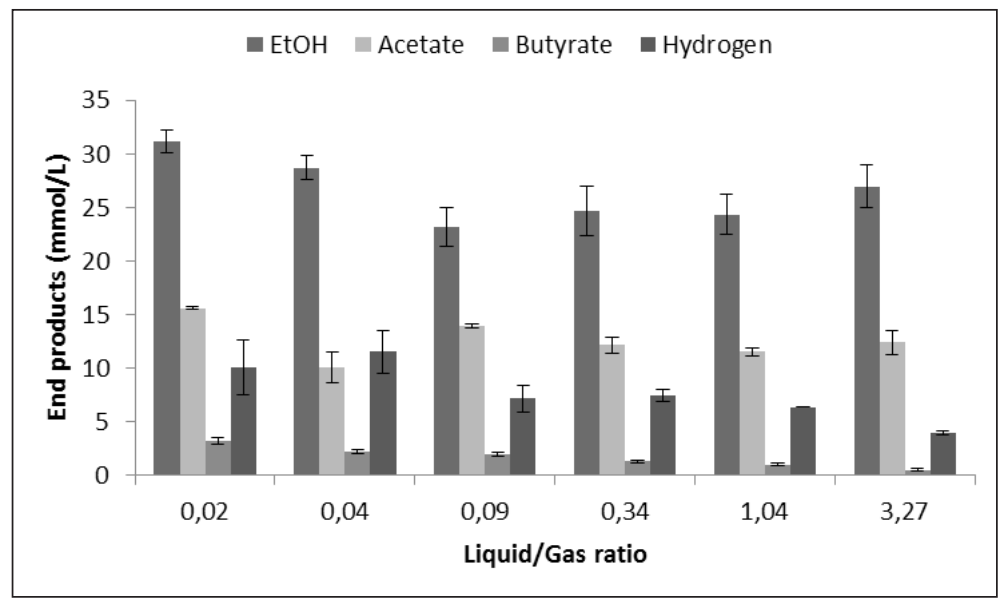

Figure 3. Effect of liquid/gas phase ratio on the end product formation for strain $\mathrm{J} 2$. Results are expressed as the average of two replicates \pm standard deviation.
A large focus of the present investigation was on the production of ethanol from lignocellulosic biomass. Production of biofuels from lignocellulosic biomass using thermophilic organisms has gained increased interest in recent years and almost exclusively with "true thermophiles" which have temperature optima above $60^{\circ} \mathrm{C}$ (Ahring et al. 1999, Georgieva et al. 2008, 
Table 1. Production of end products from hydrolysates (4.5 g L-1) from different biomasses. The biomass was either pretreated with $0.5 \% \mathrm{HCl}$ or $\mathrm{NaOH}$ or received no chemical pretreatment prior to enzymatic treatment. Data represent average \pm standard deviation of two replicate experiments. Ethanol yields in $\mathrm{mM}$ g- $1 \mathrm{dw}$ are given within brackets with control (yeast extract) subtracted. $\mathrm{Nd}=$ below detection limit $(<0.1 \mathrm{mM})$.

\begin{tabular}{|c|c|c|c|c|c|c|}
\hline \multirow[b]{2}{*}{$\begin{array}{l}\text { Substrate } \\
\text { (pretreatment) }\end{array}$} & \multicolumn{6}{|c|}{ Concentration $\left(\mathrm{mmol} \mathrm{L}^{-1}\right)$} \\
\hline & Ethanol & Acetate & Butyrate & Hydrogen & $\begin{array}{c}\text { Glucose } \\
(t=0)\end{array}$ & $\begin{array}{c}\text { Glucose } \\
(\mathrm{t}=\text { final }) \#\end{array}$ \\
\hline Control & $2.7 \pm 0.1$ & $2.7 \pm 0.1$ & $0.2 \pm 0.0$ & $2.4 \pm 0.1$ & $\mathrm{Nd}$ & $\mathrm{Nd}$ \\
\hline Whatman & $27.5 \pm 0.5$ & $9.5 \pm 0.4$ & $1.1 \pm 0.1$ & $5.1 \pm 0.6$ & $30.3 \pm 1.4$ & $9.1 \pm 0.3$ \\
\hline Whatman (acid) & $27.1 \pm 0.8$ & $10.9 \pm 0.2$ & $1.1 \pm 0.1$ & $7.8 \pm 0.4$ & $31.3 \pm 1.8$ & $7.2 \pm 0.2$ \\
\hline Whatman (alkali) & $20.4 \pm 0.7$ & $11.5 \pm 0.1$ & $4.8 \pm 0.3$ & $15.3 \pm 1.4$ & $29.5 \pm 0.4$ & $6.5 \pm 0.1$ \\
\hline Paper & $9.6 \pm 0.7$ & $8.5 \pm 0.6$ & $0.8 \pm 0.1$ & $6.6 \pm 0.3$ & $8.6 \pm 0.1$ & 0.0 \\
\hline Paper (acid) & $11.5 \pm 0.7$ & $8.9 \pm 0.2$ & $0.8 \pm 0.6$ & $6.9 \pm 0.1$ & $10.2 \pm 0.1$ & 0.0 \\
\hline Paper (alkali) & $5.1 \pm 0.5$ & $7.1 \pm 0.5$ & $1.7 \pm 0.1$ & $8.1 \pm 0.2$ & $11.3 \pm 0.1$ & 0.0 \\
\hline Grass & $10.6 \pm 0.5$ & $9.1 \pm 0.1$ & $1.7 \pm 0.0$ & $10.3 \pm 0.6$ & $9.4 \pm 0.1$ & 1.2 \\
\hline Grass (acid) & $19.7 \pm 1.9$ & $12.1 \pm 0.0$ & $2.3 \pm 0.8$ & $9.9 \pm 0.1$ & $13.9 \pm 0.1$ & 1.3 \\
\hline Grass (alkali) & $10.0 \pm 0.3$ & $10.6 \pm 0.4$ & $3.7 \pm 0.2$ & $14.4 \pm 0.5$ & $14.2 \pm 0.1$ & 2.1 \\
\hline Straw & $8.0 \pm 0.1$ & $6.9 \pm 0.2$ & $0.6 \pm 0.1$ & $6.8 \pm 0.1$ & $4.5 \pm 0.1$ & 3.0 \\
\hline Straw (acid) & $14.5 \pm 0.5$ & $10.2 \pm 0.0$ & $1.2 \pm 0.4$ & $6.6 \pm 0.0$ & $6.1 \pm 0.1$ & 5.7 \\
\hline Straw (alkali) & $14.4 \pm 0.2$ & $12.2 \pm 0.2$ & $3.6 \pm 0.5$ & $12.6 \pm 0.1$ & $13.5 \pm 0.1$ & 1.2 \\
\hline
\end{tabular}

\# For paper, grass, and straw hydrolysates, glucose was not the only sugar present but results reflected total hexoses and pentoses.

Almarsdottir et al. 2012) while little attention has been allocated to moderate thermophiles. Clostridium AK1, a moderate thermophile with a $\mathrm{T}_{\text {opt }}$ of $50^{\circ} \mathrm{C}$, was recently investigated in our laboratory and shown to produce $7.4 \mathrm{mM}$ $\mathrm{g}^{-1}$ cellulose (Whatman paper), pretreated in the same way as in the present investigation. The highest yields on grass and straw were $3.1 \mathrm{mM} \mathrm{g}^{-1}$ and $3.2 \mathrm{mM} \mathrm{g}^{-1}$ when pretreated with acid and alkali, respectively (Orlygsson, 2012). The maximum yield of ethanol from the fermentation of glucose is $2 \mathrm{~mol}$ ethanol mol hexose $^{-1}$ or $11.1 \mathrm{mM} \mathrm{g}^{-1}$ Whatman paper. Strain $\mathrm{J} 2$ produced the highest amounts of ethanol on untreated and acid pretreated Whatman paper, between 24.5 to $25.0 \mathrm{mM}$ (controls subtracted) or 5.6 to $5.8 \mathrm{mM} \mathrm{g}^{-1}(\mathrm{dw})$, respectively (Table 1). This was approximately $55 \%$ of theoretical yields which may be explained by acetate formation and that some glucose remained unutilized at the end of the incubation period.
When cellulose was pretreated with alkali, considerably less ethanol was produced; instead more butyrate and hydrogen were produced. Cultivation on lignocellulosic biomass resulted in much lower yields. The highest ethanol yields of chemically unpretreated biomass were 1.75 $\mathrm{mM} \mathrm{\textrm {g } ^ { - 1 }}$ grass. This was, however, increased to $3.77 \mathrm{mM} \mathrm{g}^{-1}$ with acid pretreatment. These yields were in a range similar to those in some recent studies on wheat straw and beet molasses by Thermoanaerobacter mathranii and Thermoanaerobacter ethanolicus (Ahrin g et al. 1999, Avci \& Donmez, 2006) but considerably lower as compared to Thermoanaerobacterium AK17 on grass hydrolysates (Almarsdottir et al. 2012). Generally, both butyrate and hydrogen production were highest using an alkali pretreated biomass. The reason for this shift in lower ethanol and higher butyrate and hydrogen production from an alkaline pretreated biomass is difficult to explain but could have been 
caused by different substrates available or the production of inhibitory compounds.

\section{CONCLUSION}

Ethanol production capacity was studied by Paenibacillus strain $\mathrm{J} 2$ isolated from an Icelandic hot spring. The strain produced a maximum of 1.45 mol ethanol mol glucose ${ }^{-1}$ and had a moderate substrate spectrum, degrading various hexoses, xylose, disaccharides and polymeric substrates to ethanol, acetate and traces of butyrate. The main drawback of the strain is its relatively low tolerance to substrate (glucose) concentrations. This limitation can however be resolved by cultivating the strain in fed-batch or continuous culture. Finally, the strain produced up to $3.77 \mathrm{mM}$ ethanol $\mathrm{g}^{-1}$ on chemically pretreated grass hydrolysates, which corresponds to up to $250 \mathrm{~L}$ of ethanol from one ton of this type of biomass.

\section{ACKNOWLEDGEMENTS}

This work was sponsored by RANNÍS, (Technology Development Fund, project RAN091016-2376 (BioFuel)), and The Research Fund of the University of Akureyri.

\section{REFERENCES}

Ahring BK, Licht D, Schmidt AS, Sommer P \& Thomsen AB 1999. Production of ethanol from wet oxidised wheat straw by Thermoanaerobacter mathranii. Bioresource Technology 68, 3-9. doi: http://dx.doi.org/10.1016/S0960-8524(98)00077-7

Almarsdottir AR, Sigurbjornsdottir MA \& Orlygsson J 2012. Effects of various factors on ethanol yields from lignocellulosic biomass by Thermoanaerobacterium AK17. Biotechnology and Bioengineering 109, 686-694. doi: http:// dx.doi.org/10.1002/bit.24346

Ash C, Priest FG \& Collins MD 1993. Molecular identification of rRNA group 3 bacilli (Ash, Farrow, Wallbanks and Collins) using a PCR probe test (Proposal for the creation of a new genus Paenibacillus). Antonie van Leeuwenhoek 64, 253260.

Avci A \& Donmez S 2006. Effect of zinc on ethanol production by two Thermoanaerobacter strains. Process Biochemistry 41, 984-989. doi: http:// dx.doi.org/10.1016/j.procbio.2005.11.007

Benardini JN, Vaishampayan, Schwendner P, Swanner E, Fukui Y, Osman S, Satomi M \& Venkateswaran K 2011. Paenibacillus phoenicis sp. nov., isolated from the Phoenix Lander assembly facility and a subsurface molybdenum mine. International Journal of Systematic and Evolutionary Microbiology 61, 1338-1343. doi: 10.1099/ijs.0.021428-0

Behrendt U, Schumann P, Stieglmeier M, Pukall R, Augustin J, Spröer C, Schwendner P, MoisslEichinger C, Ulrich A 2010. Characterization of heterotrophic nitrifying bacteria with respiratory ammonification and dentirification activity Description of Paenibacillus uliginis sp. nov., and inhabitant of fen peat soil and Paenibacillus purispatii sp. nov., isolated from a spacecraft assembly clean room. Systematic and Applied Microbiology 33, 328-336. doi: http://dx.doi. org/10.1016/j.syapm.2010.07.004

Ben-Bassad A, Lamed R \& Zeikus JG 1981. Ethanol-production by thermophilic bacteria - Metabolic control of end product formation in Thermoanaerobium brockii. Journal of Bacteriology 146, 192-199.

Bouraoui H, Rebib H, Aissa MB, Touzel JP, O'donohue M \& Manai M 2013. Paenibacillus marinum sp. nov., a thermophilic xylanolytic bacterium isolated from a marine hot spring in Tunisia. Journal of Basic Microbiology 53, 877-883. doi: http://dx.doi.org/10.1002/ jobm. 201200275

Daane LL, Harjono I, Barns SM, Launen LA, Palleroni NJ \& Haggblom MM 2002. PAHdegradation by Paenibacillus spp. and description of Paenibacillus naphthalenovorans sp. nov., a naphthalene-degrading bacterium from the rhizosphere of salt marsh plants. International Journal of Systematic and Evolutionary Microbiology 52, 131-139.

Dasman, Kajiymana S, Kawasaki H, Yagi M, Seki T, Fukusaki E \& Kobayshi A 2002. Paenibacillus glycanilyticus sp. nov. a novel species that degrades heteropolysaccharide produced by the cyanobacterium Nostoc commune. International Journal of Systematic and Evolutionary Microbiology 52, 1669-1674. doi: http://dx.doi. org/10.1099/ijs.0.02171-0 
Georgieva TI, Mikkelsen MJ \& Ahring BK 2008. Ethanol production from wet-exploded wheat straw hydrolysate by thermophilic anaerobic bacterium Thermoanaerobacter BG1L1 in a continuous immobilized reactor. Applied Biochemistry and Biotechnology 145, 99-110. doi: http://dx.doi. org/10.1007/s12010-007-8014-1

Gupta A, Murarka A, Campbell P \& Gonzales R 2009. Anaerobic fermentation of glycerol in Paenibacillus macerans: Metabolic pathways and environmental determinants. Applied and Environmental Microbiology 75, 5871-5833. doi: http://dx.doi.org/10.1128/AEM.01246-09

Hawkes FR, Dinsdale R, Hawkes DL \& Hussy I 2002. Sustainable fermentative hydrogen production: Challenges for process optimization. International Journal of Hydrogen Energy 27, 1339-1347. doi: http://dx.doi.org/10.1016/S03603199(02)00090-3

Heyndrickx M, Vandemeulebroecke, K, Scheldman P, Kersters K, De Vos P, Logan NA, Aziz AM, Ali N \& Berkely RCW 1996. A polyphasic reassessment of the genus Paenibacillus, reclassification of Bacillus lautus (Nakamura 1984) as Paenibacillus lautus comb. nov. and of Bacillus peoriae (Montefusco et al. 1993) as Paenibacillus peoriae comb. nov., and emended descriptions of P. lautus and of P. peoriae. International Journal of Systematic Bacteriology 46, 988-1003.

Jones PR 2008. Improving fermentative biomassderived $\mathrm{H}_{2}$-production by engineering microbial metabolism. International Journal of Hydrogen Energy 33, 5122-5130. doi: http://dx.doi. org/10.1016/j.ijhydene.2008.05.004

Khianngam S, Tanasupawat S, Lee JS, Lee KC \& Akaracharanya A 2009. Paenibacillus siamensis sp. nov., Paenibacillus septentrionalis sp. nov. and Paenibacillus montaniterrae sp. nov., xylanaseproducing bacteria from Thai soils. International Journal of Systematic and Evolutionary Microbiology 59, 130-134. doi: http://dx.doi. org/10.1099/ijs.0.65851-0

Lacis LS \& Lawford HG 1988. Ethanol production from xylose by Thermoanaerobacter ethanolicus in batch and continuous culture. Archives of Microbiology 150, 48-55. doi: http://dx.doi. org/10.1007/BF00409717
Laurentin A \& Edwards CA 2003. A microtiter modification of the anthrone-sulfuric acid colorimetric assay for glucose-based carbohydrates. Analytical Biochemistry 315, 143-145. doi: http:// dx.doi.org/10.1016/S0003-2697(02)00704-2

Lee F-L, Kuo H-P, Tai C-J, Yokota A \& Lo C-C 2007. Paenibacillus taiwanensis sp. nov., isolated from soil in Taiwan. International Journal of Systematic and Evolutionary Microbiology 57, 1351-1354. doi: http://dx.doi.org/10.1099/ ijs.0.64764-0

Logan NA, Clerck ED, Lebbe L, Verhelst A, Goris J, Forsyth G, Rodríguez-Díaz M, Heyndrickx M \& De Vos P 2004. Paenibacillus cineris sp. nov. and Paenibacillus cookii sp. nov., from Antartic volcanic soils and a gelatin-processing plant. International Journal of Systematic and Evolutionary Microbiology 54, 1071-1076. doi: http://dx.doi.org/10.1099/ijs.0.02967-0

Lynd LR, Grethlein HE \& Wolkin RH 1989. Fermentation of cellulosic substrates in batch and continuous culture by Clostridium thermocellum. Applied and Environmental Microbiology 55, 3131-3139.

Orlygsson J \& Baldursson. SRB 2007. Phylogenetic and physiological studies of four hydrogenproducing thermoanaerobes from Icelandic geothermal areas. Icelandic Agricultural Sciences 20, 93-106.

Orlygsson J 2012. Ethanol production from biomass by a moderate thermophile, Clostridium AK1. Icelandic Agricultural Sciences 25, 23-35.

Osman S, Satomi M \& Venkateswaran K 2006. Paenibacillus pasadenensis sp. nov. and Paenibacillus barengoltzii sp. nov., isolated from a spacecraft assembly facility. International Journal of Systematic and Evolutionary Microbiology 56, 1509-1514. doi: http://dx.doi.org/10.1099/ ijs.0.64085-0

Priest, F.G 2009. Family IV. Paenibacillaceae fam. nov. In: De Vos P, Garrity GM, Jones D, Krieg NR, Ludwig W, Rainey FA, Schleifer K-H \& Whitman WB (eds) Bergey's Manual of Systematic Bacteriology. Volume III - The Firmicutes, $2^{\text {nd }}$ ed. Springer: New York, pp. 269-327.

Rai SK, Roy JK \& Mukherjee AK 2010. Characterization of a detergent-stable alkaline protease from a novel thermophilic strain 
Paenibacillus tezpurensis sp. nov. AS-S24_II. Applied Microbiology and Biotechnology 85, 1437-1450. doi: http://dx.doi.org/10.1007/s00253009-2145-y

Scully SM, \& Orlygsson J 2015. Recent advantages in second generation ethanol production by thermophilic bacteria. Energies 8, 1-30. doi: http:// dx.doi.org/10.3390/en8010001

Sommer P, Georgieva T \& Ahring BK 2004. Potential for using thermophilic anaerobic bacteria for bioethanol production from hemicellulose. Biochemical Society Transactions 32, 283-289. doi: http://dx.doi.org/10.1042/BST0320283

Sveinsdottir M, Beck SRB \& Orlygsson J 2009. Ethanol production from monosugars and lignocellulosic biomass by thermophilic bacteria isolated from Icelandic hot springs. Icelandic Agricultural Sciences 22, 45-58.

Taylor MP, Eley KL, Martin S, Tuffin MI, Burton SG \& Cowan DA 2009. Thermophilic ethanologenesis: future prospects for secondgeneration bioethanol production. Trends in Biotechnology 27, 398-405. doi: http://dx.doi. org/10.1016/j.tibtech.2009.03.006

Ueda J, Yamamoto S \& Kurosawa N 2013. Paenibacillus thermoaerophilus sp. nov., a moderately thermophilic bacterium isolated from compost. International Journal of Systematic and Evolutionary Microbiology 63, 3330-3335. doi: http://dx.doi.org/10.1099/ijs.0.048090-0

van Niel EW, Claassen PA \& Stams AJM 2003. Substrate and product inhibition of hydrogen production by the extreme thermophile, Caldicellulosiruptor saccharolyticus. Biotechnology and Bioengineering 81, 255-262. doi: http://dx.doi.org/10.1002/bit.10463

Vesteinsdottir H, Reynisdottir D \& Orlygsson J 2011. Thiomonas islandica sp. nov., a moderately thermophilic, hydrogen- and sulfuroxidizing betaproteobacterium isolated from a hot spring. International Journal of Systematic and Evolutionary Microbiology 61, 132-137. doi: http://dx.doi.org/10.1099/ijs.0.023572-0

Weimer PJ 1984a. Control product formation during glucose fermentation by Bacillus macerans. Journal of General Microbiology 130, 103-111.
Weimer PJ 1984b. Fermentation of 6-Deoxyhexoses by Bacillus macerans. Applied and Environmental Microbiology 47, 263-267.

Wiegel J, Carreira LH, Mothershed CP \& Puls J 1983. Production of ethanol from bio-polymers by anaerobic, thermophilic, and extreme thermophilic bacteria. II. Thermoanaerobacter ethanolicus JW200 and its mutants in batch cultures and resting cell experiments Biotechnology and Bioengineering. 13, 193-205.

Zhou Y, Gao S, Wei D-Q, Yang L-L, Huang X, He J, Zhang Y-J, Tang S-K, Li W-J 2012. Paenibacillus thermophilus sp. nov., a novel bacterium isolated from a sediment of hot spring in Fujian providence, China. Antonie van Leeuwenhoek 102, 601-609. doi: http://dx.doi.org/10.1007/s10482-012-9755-6

Manuscript received 11 April 2014 Accepted 13 November 2014 